\title{
CORRIGENDUM
}

\section{Regulation of NOTCH signaling by reciprocal inhibition of HES1 and Deltex 1 and its role in osteosarcoma invasiveness}

P Zhang, Y Yang, R Nolo, PA Zweidler-McKay and DPM Hughes

Oncogene (2012) 31, 4732; doi:10.1038/onc.2012.429

Correction to: Oncogene (2010) 29, 2916-2926; doi:10.1038/ onc.2010.62; published online 8 March 2010

Following the publication of this manuscript ${ }^{1}$ we obtained new information, including corrected DNA fingerprint analysis, indicating the cells lines OS 187 and COL do not represent osteosarcoma. Our group was the first to report the characterization of these lines. ${ }^{2}$

OS 187 has a DNA fingerprint identical to HCT 15, a colon cancer line included in the NCl60 panel. COL, while unique, has biologic features indicating that it is a neuroblastoma, rather than an osteosarcoma. The data confirming COL's identity as a neuroblastoma have just been reported. ${ }^{3}$

The purpose of this publication was to report the reciprocal regulation by Hes 1 and Deltex of Notch pathway activity. It was never the intent of the authors to suggest that this function was unique to osteosarcoma, and the correct identification of the cell lines used in this report, reflecting diverse tumor types, only serves to confirm that the observations can be generalized. We believe that these data continue to reflect the biology and regulation of Notch pathway signaling.

\section{REFERENCES}

1 Zhang P, Yang Y, Nolo R, Zweidler-McKay PA, Hughes DPM. Regulation of NOTCH signaling by reciprocal inhibition of HES1 and Deltex 1 and its role in osteosarcoma invasiveness. Oncogene 2010; 29: 2916-2926.

2 Hughes DPM, Thomas DG, Giordano TJ, Baker LH, McDonagh KT. Cell surface expression of epidermal growth factor receptor and Her-2 with nuclear expression of Her-4 in primary osteosarcoma. Cancer Res 2004; 64: 2047-2053.

3 Hua Y, Gorshkov K, Yang Y, Wang W, Zhang N, Hughes DPM. Slow down to stay alive: HER4 protects against cellular stress and confers chemoresistance in neuroblastoma. Cancer (e-pub ahead of print 13 March 2012; doi:10.1002/cncr.27496). 